\title{
Defective Retrotranslocation Causes Loss of Anti-Bax Function in Human Familial Prion Protein Mutants
}

\author{
Julie Jodoin, ${ }^{1,2}$ Stéphanie Laroche-Pierre, ${ }^{1,2}$ Cynthia G. Goodyer, ${ }^{3}$ and Andréa C. LeBlanc ${ }^{1,2}$ \\ ${ }^{1}$ Bloomfield Center for Research in Aging, Lady Davis Institute for Medical Research, Sir Mortimer B. Davis Jewish General Hospital, Montréal, Québec, \\ Canada H3T 1E2, and Departments of ²Neurology and Neurosurgery and ${ }^{3}$ Pediatrics, McGill University, Montréal, Québec, Canada H3A 2T5
}

\begin{abstract}
Prion protein (PrP) inhibits the activation of proapoptotic Bax in primary human neurons and MCF-7 cells. Because neuronal apoptosis occurs in human prion diseases, here we examine the anti-Bax function of familial PrP mutants. All Creutzfeldt-Jakob disease and fatal familial insomnia-associated prion protein mutations partially or completely lose the anti-Bax function in human neurons and, except for A117V and V203I, in MCF-7 cells. The ability of the mutants to protect against Bax-mediated cell death is divided into three groups: (1) group I, retention of anti-Bax function in both the Val ${ }^{129}$ and Met ${ }^{129}$ mutants; (2) group II, retention of anti-Bax function only in Val ${ }^{129}$ mutants; and (3) group III, reduction or no anti-Bax function in Val ${ }^{129}$ and Met ${ }^{129}$ mutants. The loss of anti-Bax function in these PrP mutants correlates completely with a significant decrease in the production of cytosolic $\operatorname{PrP}$, a form of PrP shown previously to have anti-Bax function in human neurons. Cotransfection of the full-length PrP mutants with wild-type or mutant cytosolic PrP, but not with wild type full-length PrP, rescues the anti-Bax function of PrP. The results show that the failure of PrP mutants to produce cytosolic $\operatorname{PrP}$ is responsible for the loss of anti-Bax function and that the effect of the PrP mutants is dominant over wild-type PrP. Furthermore, these results imply that misfolded PrP that escapes retrotranslocation could accumulate at the cell surface and cause neuronal dysfunction.
\end{abstract}

Key words: prion protein; apoptosis; Bax; familial prion protein mutations; cytosolic PrP; retrotranslocation

\section{Introduction}

Prion protein $(\mathrm{PrP})$ is a glycoprotein that is synthesized through the secretory pathway and accumulates as a glycosyl phosphatidylinositol (GPI) anchored-protein at the cell surface (Caughey et al., 1989). In addition, $\mathrm{PrP}$ is retrotranslocated from the endoplasmic reticulum to the cytosol as cytosolic $\operatorname{PrP}(\mathrm{CyPrP})(\mathrm{Za}-$ nusso et al., 1999; Ma and Lindquist, 2001; Yedidia et al., 2001; Roucou et al., 2003). PrP is highly expressed in brain, and its sequence is well conserved among mammalian species (Kretzschmar et al., 1986; Wopfner et al., 1999), indicating an important function for the normal cellular PrP. PrP promotes cell survival (for review, see Roucou et al., 2004). Neuronal PrP knock-out cells are more susceptible to apoptosis than PrPexpressing cells (Kuwahara et al., 1999). PrP prevents tumor necrosis factor- $\alpha$-induced cell death in the breast carcinoma MCF-7 cells (Diarra-Mehrpour et al., 2004). In primary cultures of human neurons and in MCF-7 cells, PrP prevents the Bax conformational change involved as the first step of Bax activation

Received Jan. 30, 2006; accepted March 22, 2007.

This work was supported by National Institutes for Health Grant 1R01 NS-40431, Canadian Institutes of Health Research Grant MOP49594, and the Fonds de Recherche en Santé du Québec. We are grateful to Dr. Neena Singh (Case Western Reserve University, Cleveland, OH) for providing the E200K, V2031, and E2110 PrP mutants, Dr. Man-Sun Sy (Case Western Reserve University, Cleveland, OH) for providing the $8 \mathrm{H} 4$ antibody, the Birth Defects Research Laboratory (University of Washington, Seattle, WA) for providing conceptal tissue for research (National Institutes of Health Grant HD 000836), Jennifer Hammond for the culture of the human neurons, and Iwona Link, Myriam Pilon, Thi Huong Tra Truong, and Paresa Giannopoulos for the purification of DNA.

Correspondence should be addressed to Dr. Andréa LeBlanc, The Bloomfield Center for Research in Aging, Lady Davis Institute for Medical Research, The Sir Mortimer B. Davis Jewish General Hospital, 3755 chemin Côte SteCatherine, Montréal, Québec, Canada H3T 1E2. E-mail: andrea.leblanc@mcgill.ca.

DOI:10.1523/JNEUROSCI.0957-07.2007

Copyright $\odot 2007$ Society for Neuroscience $\quad$ 0270-6474/07/275081-11\$15.00/0 into a proapoptotic protein and subsequently Bax-mediated mitochondrial cytochrome $c$ release and cell death (Bounhar et al., 2001; Roucou et al., 2003, 2005). Furthermore, PrP is able to overcome Bax-mediated cell death in yeast cells (Bounhar et al., 2006). Because Bax is a strong inducer of neuronal apoptosis (White et al., 1998), this could be a very important function for PrP.

Disease-specific mutations of the PrP gene (PRNP) correspond to $10-15 \%$ of human transmissible spongiform encephalopathies. More than 30 dominant single point mutations and insertions have been identified in PRNP; 11 single point mutations confer Creutzfeldt-Jacob disease (CJD) (Windl et al., 1999; Gambetti et al., 2003). In addition to the pathogenic mutations in $P R N P$, a polymorphism at codon 129 encodes either a methionine $\left(\mathrm{Met}^{129}\right)$ or a valine $\left(\mathrm{Val}^{129}\right)$. The codon 129 polymorphism affects the susceptibility to prion diseases, the phenotype of CJD, and dictates the manifestation of either CJD or fatal familial insomnia (FFI) associated with the D178N PrP mutation (Goldfarb et al., 1992; Wadsworth et al., 2004).

Because neuronal apoptosis occurs in CJD and FFI patients (Dorandeu et al., 1998; Gray et al., 1999; Kawashima et al., 2001; Ferrer, 2002), here we investigate the anti-Bax function of both the $\mathrm{Met}^{129}$ and $\mathrm{Val}^{129}$ alleles of 11 PrP CJD mutations, one FFI mutation, and one Gerstmann-Straussler-Scheinker disease (GSS) mutation. We show that all familial PrP mutations tested decrease or abolish the anti-Bax function in primary human neurons and, except for A117V and V203I, in MCF-7 cells. The loss of anti-Bax function in these PrP mutants correlates completely with a significant decrease in the production of CyPrP, a form of PrP shown previously to have anti-Bax function in human neu- 
rons. Furthermore, coexpression of normal or mutant cytosolic PrP, but not full-length PrP, rescues the loss of anti-Bax function in PrP mutants. These results suggest that CyPrP is essential to the anti-Bax function of PrP and that the defective retrotranslocation of PrP mutants is dominant.

\section{Materials and Methods}

Cell cultures

Human primary neurons, obtained from fetal brains with ethical approval from the McGill University Institutional Review Board, were cultured as described previously (LeBlanc et al., 1997). Breast carcinoma MCF-7 cells and N2a mouse neuroblastoma cells were obtained from American Type Culture Collection (Manassas, VA) and maintained in DMEM containing $10 \%$ fetal bovine serum.

Cloning, site-directed mutagenesis of human $\mathrm{Pr} P$, and sequencing of $\operatorname{PrP}$ mutants

Human wild-type (WT) PrP carrying a valine at the codon 129 (Bounhar et al., 2001) was subcloned in the NotI and XhoI sites of the pcDNA3.1 $(+)$ vector (Invitrogen, Burlington, Ontario, Canada). Single point mutations in PrP were produced from human WT PrP using the QuikChange Site-Directed Mutagenesis protocol (Stratagene, La Jolla, CA). Forward primers used to produce the different $\operatorname{PrP}$ mutations are listed below, and substituted nucleotides are indicated in bold: A117V, 5'-CTGGTGCTGCAGTAGCTGGGGCGGTGG-3'; V180I, 5' -CAACTTTGTCCACGACTGCATCAATATCACAATCAAGC-3'; T188A, 5' CAATCAAGCAGCACGCGGTCACCACAACC-3'; E196K, 5' -ACAACCACCAAGGGGAAGAACTTCACCGAGAC-3'; R208H, 5' -CGTTAAGATGATGGAGCACGTGGTTGAGCAGATG-3'; V210I, 5-GATGATGGAGCGCGTGATTGAGCAGATGTGTATC-3'; M232R, 5' GAGGATCGAGCAGGGTCCTCTTCTCC-3'; P238S, 5'-GTCCTCTTCTCCTCTTCACCTGTGATCCTCC-3'; 129M， 5-CCTTGGCGGCTACATGCTGGGAAGTGC-3'; and 129V, 5-CTTGGCGGCTACGTGCTGGGAAGTGC-3'. PrP D178N and PrP T183A had been obtained previously (Bounhar et al., 2001). PrP mutants E200K, V203I, and E211Q were a kind gift from Dr. Neena Singh (Case Western Reserve University, Cleveland, $\mathrm{OH}$ ). All PrP mutations were confirmed by sequencing using the Sequenase Version 2.0 DNA Sequencing kit (USB, Cleveland, $\mathrm{OH}$ ).

Enhanced green fluorescent protein (EGFP) and EGFP-Bax cDNAs were amplified by PCR amplification from pCep $4 \beta$-EGFP and pCep $4 \beta-$ EGFP-Bax constructs (Roucou et al., 2003) with the upstream primer 5'-TTTGGTACCATGGTGAGCAAGGGCGAG-3' and the downstream primer 5'-GGGAGATCTACTTGTACAGCTCGTCCAT-3' for EGFP or the upstream primer 5' ${ }^{\prime}$-TAAGCGGCCGCTATGGTGAGCAAGGGCGAGGA-3' and the downstream primer 5' -CGCGGTACCTCAGCCCATCTTCTTCCACATC-3' for EGFP-Bax. The PCR products were cloned into the pBudCE4.1 vector (designed for independent expression of two genes; Invitrogen) downstream of the elongation factor $1 \alpha$ (EF$1 \alpha$ ) promoter using the KpnI and BglII sites for EGFP or the NotI and $K p n I$ sites for EGFP-Bax, generating pBud-EGFP and pBud-EGFP-Bax, respectively. WT PrP and PrP mutant cDNAs were PCR amplified from pcDNA3.1(+)-PrP or PrP mutants with the upstream primer 5'ATATGTCGACATGGCGAACCTTGGCTGCTGGAT-3' and the downstream primer 5'-CGCGTCTAGATCATCCCACTATCAGGAAGAT- $3^{\prime}$ and cloned into the SalI and $\mathrm{XbaI}$ sites under the cytomegalovirus (CMV) promoter in the pBud-EGFP or pBud-EGFP-Bax to generate pBud-EGFP/PrP or PrP mutants and pBud-EGFP-Bax/PrP or PrP mutants. Moreover, WT and mutant PrP cDNAs from pBud-EGFP/PrP or PrP mutants were subcloned into the BamH I and HindIII sites of the pCep $4 \beta$ vector to generate pCep $4 \beta-\operatorname{PrP}$ or PrP mutants. CyPrP (amino acids 23-231) and CyPrP GPI (amino acids 23-253) from WT PrP and PrP mutants were produced by PCR amplification of pBud-EGFP/PrP or PrP mutants with the upstream primer 5'-GCAAGTCGACATGAAGAAGCGCCCGAAGCCTG-3' and the downstream primer 5'-GCCAGTACTCAGCTCGATCCTCTCTGGTAATAGGC-3' for CyPrP or 5'-CGCGTCTAGATCATCCCACTATCAGGAAGAT-3' for CyPrP GPI and cloned into the SalI and ScaI sites or ScaI and XbaI sites, respectively, of pBud-EGFP. CyPrP and CyPrP GPI were then subcloned into the BamH I and HindIII sites of the $\mathrm{pCep} 4 \beta$ vector to generate pCep $4 \beta-$ CyPrP or pCep $4 \beta-$ CyPrP GPI.

\section{Analysis of the PrP polymorphism at codon 129}

The Met/Val ${ }^{129}$ polymorphism of PrP in MCF-7 cells and human neurons was detected by PCR amplification with the upstream 5'-GGAACAAGCCGAGTAAGCTAAAAACCAACATGAAGCAC- ${ }^{\prime}$ ' primer and the downstream 5'-GGTTGTGGTGACCGCGTGCTGCTTGATTG-3' primer. The PCR product was digested with NspI and separated on a $3 \%$ agarose gel. The $\mathrm{Met}^{129}$ corresponds to three fragments of 75, 90, and 116 $\mathrm{bp}$, whereas the $\mathrm{Val}^{129}$ corresponds to two fragments of 116 and $165 \mathrm{bp}$. The MCF-7 cell endogenous PrP is heterozygous at codon 129. Endogenous PrP in human neurons was homozygous for Met, homozygous for Val, or heterozygous at codon 129.

\section{Transfections}

For cell death assays, human primary neurons were plated at a density of $3 \times 10^{6}$ cells $/ \mathrm{ml}$ onto poly-D-lysine-coated $(20 \mu \mathrm{g} / \mathrm{ml}$; Sigma, Oakville, Ontario, Canada) plastic coverslips, and MCF-7 cells were plated at $2.5 \times$ $10^{5}$ cells $/ \mathrm{ml}$ onto glass coverslips in 24 -well plates. The human neurons and MCF-7 cells on coverslips were transfected using the Helios Gene Gun system (Bio-Rad, Mississauga, Ontario, Canada) at a shooting pressure of 100 and 220 psi, respectively, according to the protocol of the manufacturer. Transfection cartridges were prepared with $0.033 \mathrm{mg}$ of DNA, $4.2 \mathrm{mg}$ of gold microcarrier beads in $0.1 \mathrm{ml}$ of $1 \mathrm{~m}$ calcium chloride, and $0.1 \mathrm{ml}$ of $0.05 \mathrm{M}$ spermidine, as described previously (Roucou et al., 2005). The microcarrier loading quantity of the transfection cartridges was $0.125 \mathrm{mg}$ gold/shot, and the DNA loading ratio was $1 \mu \mathrm{g}$ DNA/shot. When cells were transfected with two constructs, a 1:3 ratio of pBudEGFP-Bax/PrP or PrP mutants to pCep $4 \beta-\operatorname{PrP}$, pCep $4 \beta-$-CyPrP, pCep $4 \beta-$-CyPrP mutant, pCep $4 \beta-$ CyPrP GPI, or pCep $4 \beta-$ CyPrP GPI mutant was used for the preparation of cartridges. For PrP expression, MCF-7 cells were plated in six-well plates at $1.5 \times 10^{6}$ cells $/ \mathrm{ml}$ or in 24 -well plates at $2.5 \times 10^{5} \mathrm{cells} / \mathrm{ml}$ and transfected with 4 or $0.8 \mu \mathrm{g}$ DNA, respectively, at a 3:1 ratio with pCep $4 \beta$-PrP:pCep $4 \beta$-EGFP, using Lipofectamine 2000 (Invitrogen) as described previously (Roucou et al., 2005). The transfection efficiency was measured by counting EGFP-positive cells versus the total number of cells, using a Nikon (Mississauga, Ontario, Canada) eclipse TE2000-U microscope. The transfection efficiency in MCF-7 cells was constant at $20 \%$ for all mutants. N2a cells were plated in six-well plates at $0.8 \times 10^{6}$ cells $/ \mathrm{ml}$ and transfected with $4 \mu \mathrm{g}$ of pCep $4 \beta-\operatorname{PrP}$ or PrP mutants, pCep $4 \beta-\mathrm{CyPrP}$ or CyPrP mutants, or pCep $4 \beta-$ CyPrP GPI or CyPrP GPI mutants using Lipofectamine 2000. The transfection efficiency was $70 \%$.

\section{Cell death measurement}

Twenty hours after transfection, human neurons and MCF-7 cells were washed with PBS and fixed for $20 \mathrm{~min}$ at room temperature in $4 \%$ paraformaldehyde and $4 \%$ sucrose in PBS ( $150 \mathrm{~mm} \mathrm{NaCl}, 2.7 \mathrm{~mm} \mathrm{KCl}, 1.3 \mathrm{~mm}$ $\mathrm{KH}_{2} \mathrm{PO}_{4}$, and $8.1 \mathrm{mM} \mathrm{Na}_{2} \mathrm{HPO}_{4}, \mathrm{pH} 7.4$ ), and the chromatin was stained 20 min with $1 \mu \mathrm{g} / \mathrm{ml}$ Hoechst 33342 in PBS (Sigma). Cell death was measured by counting EGFP-positive cells displaying condensed chromatin versus the total number of EGFP-positive cells, using a Nikon eclipse TE2000-U microscope.

\section{Detergent solubility assay}

Forty-eight hours after transfection, MCF-7 cells in six-well plates were lysed with $0.2 \mathrm{ml}$ of lysis buffer [ $150 \mathrm{~mm} \mathrm{NaCl}, 2 \mathrm{~mm}$ EDTA, $0.5 \%$ Triton $\mathrm{X}-100(\mathrm{v} / \mathrm{v}), 0.5 \%$ sodium deoxycholate (w/v), and $50 \mathrm{~mm}$ Tris- $\mathrm{HCl}, \mathrm{pH}$ 7.5) for $20 \mathrm{~min}$ at $4^{\circ} \mathrm{C}$. After a centrifugation at $11,500 \times g$ for $10 \mathrm{~min}$ at $4^{\circ} \mathrm{C}$, the supernatant was collected and the detergent insoluble pellet was resuspended in $0.2 \mathrm{ml}$ of Laemli's sample buffer [2\% SDS (w/v), $5 \%$ $\beta$-mercaptoethanol (v/v), $10 \%$ glycerol (v/v), $0.01 \%$ bromophenol blue $(\mathrm{w} / \mathrm{v})$, and $62.5 \mathrm{~mm}$ Tris- $\mathrm{HCl}, \mathrm{pH} 6.8]$. The supernatant proteins were precipitated with $4 \mathrm{vol}$ of ice-cold methanol overnight at $-20^{\circ} \mathrm{C}$ and solubilized in the Laemli's sample buffer.

\section{Western blot analyses}

The proteins were separated in a $15 \%$ SDS-PAGE and transferred to polyvinylidene fluoride membranes, and $\operatorname{PrP}$ was detected with 1:2500 
3F4 antibody (anti-PrP $\mathrm{P}_{109-112}$ ) (Kascsak et al., 1987). When indicated, 1:1000 polyclonal R155 antiserum (anti-PrP ${ }_{36-56}$; produced in our laboratory) or 1:1000 6H4 (anti-PrP ${ }_{144-156}$; Prionics, Schlieren, Switzerland) and 1:1000 8H4 (anti-PrP ${ }_{170-180}$; Dr. Man-Sun Sy, Case Western Reserve University, Cleveland, $\mathrm{OH}$ ) were used for PrP detection. Antibodies specific for $\beta$-actin (1:1000, Clone AC-15; Sigma), GFP (1:500, B-2; Santa Cruz Biotechnology, Santa Cruz, CA), cytosolic heat shock protein 70 (Hsp70) (1:1000; Stressgen Biotechnologies, Victoria, British Columbia, Canada), mitochondrial Hsp70 (1:1000, Clone JG1; Affinity BioReagents, Golden, CO), cytochrome $c$ (1:1000, Clone 7H8.2C12; BD Pharmingen, Mississauga, Ontario, Canada), and Tau (1:1000, Clone T-5530: Sigma) were also used for Western blot analyses. Immunoreactivity was detected with 1:5000 anti-mouse or rabbit IgG conjugated to horseradish peroxidase secondary antibodies (Jackson ImmunoResearch, West Grove, PA) using chemiluminescence (GE Healthcare, Baie d'Urfe, Quebec, Canada).

\section{Metabolic labeling of $\operatorname{PrP}$}

Forty-eight hours after transfection, MCF-7 cells were starved for $1 \mathrm{~h}$ in methionine-free DMEM and metabolically labeled for $3 \mathrm{~h}$ with 100 $\mu \mathrm{Ci} / \mathrm{ml}\left[{ }^{35} \mathrm{~S}\right]$ methionine. Proteins were extracted and PrP was immunoprecipitated using the anti-PrP R155 antiserum, as described previously (Bounhar et al., 2001). The immune complexes were separated in a $15 \%$ SDS-PAGE and subjected to autoradiography.

\section{PrP secretion in cell culture media}

Forty-eight hours after transfection, MCF-7 cells in 24-well plates were washed once with serum-free DMEM, and fresh DMEM was added for $6 \mathrm{~h}$. The cell culture media were then collected and centrifuged $5 \mathrm{~min}$ at $2000 \times g$. The cells were washed with cold PBS and lysed with lysis buffer. All of the proteins from the supernatant and $20 \%$ of the cell lysate were precipitated with 4 vol of ice-cold methanol overnight at $-20^{\circ} \mathrm{C}$, resuspended in Laemli's sample buffer, and submitted to Western blotting against 3F4. The intensity of the protein bands were analyzed with a Personal densitometer SI (Molecular Dynamics, Sunnyvale, CA), and the ratio of secreted PrP over cellular PrP was calculated.

\section{Phosphatidylinositol-phospholipase C treatment}

Phosphatidylinositol-phospholipase $C$ treatment of protein extracts. One hundred micrograms of protein extracts from transfected MCF-7 cells were treated with $0.0625 \mathrm{U}$ of phosphatidylinositol-phospholipase $\mathrm{C}$ (PI-PLC) (Sigma) for $18 \mathrm{~h}$ at $37^{\circ} \mathrm{C}$ in the presence of complete protease inhibitor cocktail (Roche, Laval, Quebec, Canada).

PI-PLC treatment of MCF-7 cells. Forty-eight hours after transfection, MCF-7 cells in 24-well plates were washed once with DMEM, and fresh DMEM containing $0.5 \mathrm{U} / \mathrm{ml}$ PI-PLC was added for $2 \mathrm{~h}$. The cell culture media were collected and centrifuged $5 \mathrm{~min}$ at $2000 \times \mathrm{g}$. The cells were washed with cold PBS and lysed with lysis buffer. All of the proteins from the supernatant and $20 \%$ of the cell lysate were precipitated with $4 \mathrm{vol}$ of ice-cold methanol overnight at $-20^{\circ} \mathrm{C}$, resuspended in Laemli's sample buffer, and submitted to Western blotting against 3F4.

\section{Proteinase K, peptide-N-glycosidase F, and endoglycosidase} $H$ digestion

Resistance to proteinase K (PK) was assessed by incubating $100 \mu \mathrm{g}$ of proteins from MCF-7 cells extracted in lysis buffer for $20 \mathrm{~min}$ on ice with $2 \mu \mathrm{g} / \mathrm{ml}$ PK. For peptide-N-glycosidase F (PNGase F) and endoglycosidase $\mathrm{H}$ (Endo $\mathrm{H}$ ) digestions, $100 \mu \mathrm{g}$ of proteins from MCF-7 cells extracted in lysis buffer were adjusted to $0.5 \%$ SDS, boiled $10 \mathrm{~min}$, and digested with $2 \mathrm{U}$ of PNGase F (New England Biolabs, Pickering, Ontario, Canada) for $18 \mathrm{~h}$ at $37^{\circ} \mathrm{C}$ or with $25 \mathrm{U}$ of Endo $\mathrm{H}$ (New England Biolabs) for $1 \mathrm{~h}$ at $37^{\circ} \mathrm{C}$ in the presence of protease inhibitors, as specified by the manufacturer. The reaction was terminated by the addition of Laemli's sample buffer and by boiling 2 min before submitting to Western blotting.

\section{Subcellular fractionation}

Subcellular fractionation was performed as described previously (Roucou et al., 2003) with some modifications. Twenty-four hours after transfection with pCep4 $\beta$-PrP or PrP mutant, N2a cells were treated with 0.25 $\mu \mathrm{M}$ epoxomycin (BioMol, Plymouth Meeting, PA) and $5 \mu \mathrm{g} / \mathrm{ml}$ brefeldin
A (BFA) (Sigma) for $18 \mathrm{~h}$. Cells were washed with cold PBS and homogenized with 30 strokes in a Dounce homogenizer in homogenization buffer [ $8 \%$ sucrose (w/v), $20 \mathrm{~mm} \mathrm{HCl-tricine,} \mathrm{pH} 7.8$, and $1 \mathrm{~mm}$ EDTA]. The homogenate was centrifuged three times $5 \mathrm{~min}$ at $2000 \times \mathrm{g}$ to eliminate unbroken cells and nuclei and then centrifuged at $100,000 \times g$ for $30 \mathrm{~min}$. The supernatant and the pellet represent the cytosolic and membrane fractions, respectively. The pellet was resuspended in lysis buffer, and proteins from the supernatant were precipitated with 4 vol of icecold methanol overnight at $-20^{\circ} \mathrm{C}$. The intensity of the proteins obtained from Western blot analyses was analyzed with a Personal densitometer SI (Molecular Dynamics), and the ratio of cytosolic PrP over membrane PrP was calculated.

\section{Statistical analysis}

The statistical significance of the results was analyzed by ANOVA followed by Scheffé's post hoc analysis, using StatView (SAS Institute, Cary, NC). A $p$ value of $<0.05$ was taken as a significant difference. The correlation coefficient and its statistical significance were determined using a Fisher's $r$ to $z$ transformation (StatView).

\section{Results}

\section{All PrP mutants, except A117V and V203I, partially or completely lose anti-Bax function of PrP in MCF-7 cells}

To investigate the function of familial human $\operatorname{PrP}$ mutants against Bax-mediated cell death, we chose the breast carcinoma MCF-7 cell line as described previously (Roucou et al., 2005). MCF-7 cells do not express detectable endogenous levels of PrP and are transfected with relatively high efficiency, allowing us to study mutant $\operatorname{PrP}$ expression biochemically. The bigenic pBudCE4.1 vector was used for the study because we can express the Bax protein under the EF- $1 \alpha$ promoter and $\operatorname{PrP}$ or PrP mutants under the CMV promoter. Furthermore, the CMV promoter is not highly expressed in MCF-7 cells and permits the study of the function of physiological levels of the mutant PrPs. MCF-7 cells are resistant to EGFP toxicity, but overexpression of Bax protein fused $\mathrm{N}$-terminally with EGFP under the EF- $1 \alpha$ promoter induces Bax-specific mediated cell death and allows visualization of the transfected cells (Roucou et al., 2005). All PrP mutations in this study are associated with CJD, except for the PrP mutations A117V and Met ${ }^{129} \mathrm{D} 178 \mathrm{~N}$, which are associated with GSS and FFI, respectively (Fig. $1 A$ ). Each point mutation has been generated with a valine as well as with a methionine at codon 129. Eight of these PrP mutations are located at the C-terminal B or $\mathrm{C} \alpha$-helices of the protein. Only one mutation is between the $\mathrm{B}$ and $\mathrm{C} \alpha$-helices, two mutations are in the GPI signal peptide, and one is within the transmembrane domain.

Expression of EGFP-Bax alone in MCF-7 cells induces $61 \%$ cell death (Fig. 1 B). When coexpressed with EGFP-Bax, Val ${ }^{129}$ or Met ${ }^{129}$ WT PrP decreases cell death by $50 \%$. This is lower than observed against non-EGFP-tagged Bax, which is less toxic than EGFP-Bax, but it is still sufficient to analyze the anti-Bax function of PrP (Bounhar et al., 2001; Roucou et al., 2003). Compared with WT PrP, $63 \%$ of Val/Met ${ }^{129}$ PrP mutants partially or completely lose their capacity to inhibit Bax-mediated cell death. Of these, $83 \%$ of $\mathrm{Met}^{129} \mathrm{PrP}$ mutants partially or completely lose their anti-Bax function compared with $42 \%$ of $\mathrm{Val}^{129} \mathrm{PrP}$ mutants. The inhibition of Bax-induced cell death by PrP mutants can be separated into three groups (Fig. $1 B$, Table 1). In the first group, the Met/Val ${ }^{129} \mathrm{~A} 117 \mathrm{~V}$ and V203I anti-Bax function is normal. In the second group, the anti-Bax function is partially lost in Met $^{129}$ V180I, E200K, or T188A and completely lost in Met ${ }^{129}$ E196K and R208H PrP mutants. In contrast, the Val ${ }^{129}$ mutants completely retain the anti-Bax function. In the third group, the $\mathrm{Val}^{129}$ and $\mathrm{Met}^{129} \mathrm{E} 211 \mathrm{Q}, \mathrm{D} 178 \mathrm{~N}, \mathrm{M} 232 \mathrm{R}, \mathrm{V} 210 \mathrm{I}$, and P238S partially or completely lose the anti-Bax function. 
The amino acid substitution of the PrP mutants can change the amino acid charge or polarity. Interestingly, the two mutants that retain the anti-Bax function of $\operatorname{PrP}$ in MCF-7 cells have conserved mutation (Table 1). However, two other conserved substitutions in $\mathrm{Met}^{129} \mathrm{~V} 180 \mathrm{I}$ and Met/ Val ${ }^{129}$ V210I partially or completely lose the anti-Bax function, respectively. Therefore, simple nonconserved substitution of the amino acid cannot account for the loss of anti-Bax function. PrP mutations that alter the charge or the polarity of the substituted amino acid result in the loss of anti-Bax function but, in some cases, only if the codon 129 encodes methionine. Generally, the Met ${ }^{129} \operatorname{PrP}$ mutants have less anti-Bax function than $\mathrm{Val}^{129} \mathrm{PrP}$ mutants. Furthermore, the position of the PrP mutations in the secondary structure of the protein does not correlate with the loss of anti-Bax function. For example, neither the mutant with the Met ${ }^{129}$ or $\mathrm{Val}^{129} \mathrm{~V} 210 \mathrm{I}$ conserved mutation in $\alpha$-helix C protect against Bax-mediated cell death, whereas both mutants with the conserved Met ${ }^{129}$ and Val ${ }^{129}$ V203I mutation in $\alpha$-helix $\mathrm{C}$ protect completely against Bax-mediated cell death. Together, these results indicate that there is no consensus change in either the polarity or charge of the substituted amino acids in PrP mutants that correlate with the loss of anti-Bax function.

The background levels of cell death in nontransfected and pBud-EGFPtransfected MCF-7 cells are $5.4 \pm 0.8$ and $5.2 \pm 0.7 \%$, respectively, indicating that EGFP is not toxic. Only the $\mathrm{Val}^{129} \mathrm{E} 196 \mathrm{~K}$, Met/Val ${ }^{129}$ V210I, and $\mathrm{Met}^{129} \mathrm{P} 238 \mathrm{~S} \mathrm{mu}-$ tants are weakly cytotoxic (Fig. 1C). The cells look healthy and normal, indicating that the expression of the mutant PrPs is not inducing cell death. There is no correlation between PrP mutant cytotoxicity and loss of the anti-Bax function because the $\mathrm{Val}^{129} \mathrm{E} 196 \mathrm{~K}$ is slightly cytotoxic yet completely retains its anti-Bax function. Moreover, most of the PrP mutants that lose their anti-Bax function are not cytotoxic. These results show that the loss of anti-Bax function is not a direct consequence of mutant PrP-induced cytotoxicity.

\section{The PrP M232R and PrP P238S} mutations in the GPI anchor signal peptide allow cleavage of the $\mathrm{C}$-terminal peptide and the addition of the GPI anchor

Normally, the C-terminal signal peptide of $\mathrm{PrP}$ is cleaved from amino acids 232253 for the addition of the GPI anchor (Englund, 1993). Therefore, we investi-

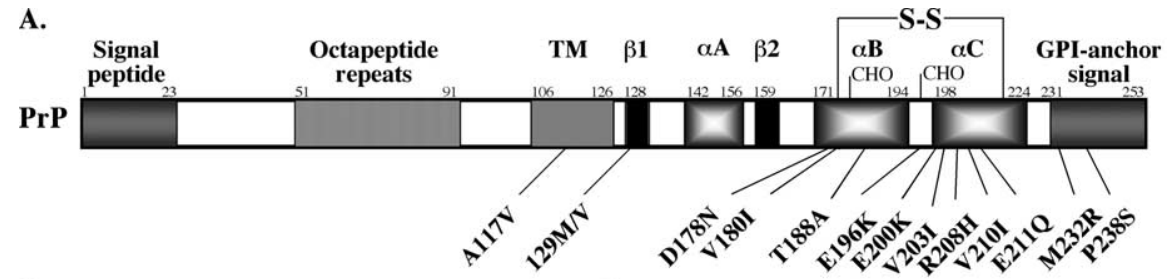

B.

C.
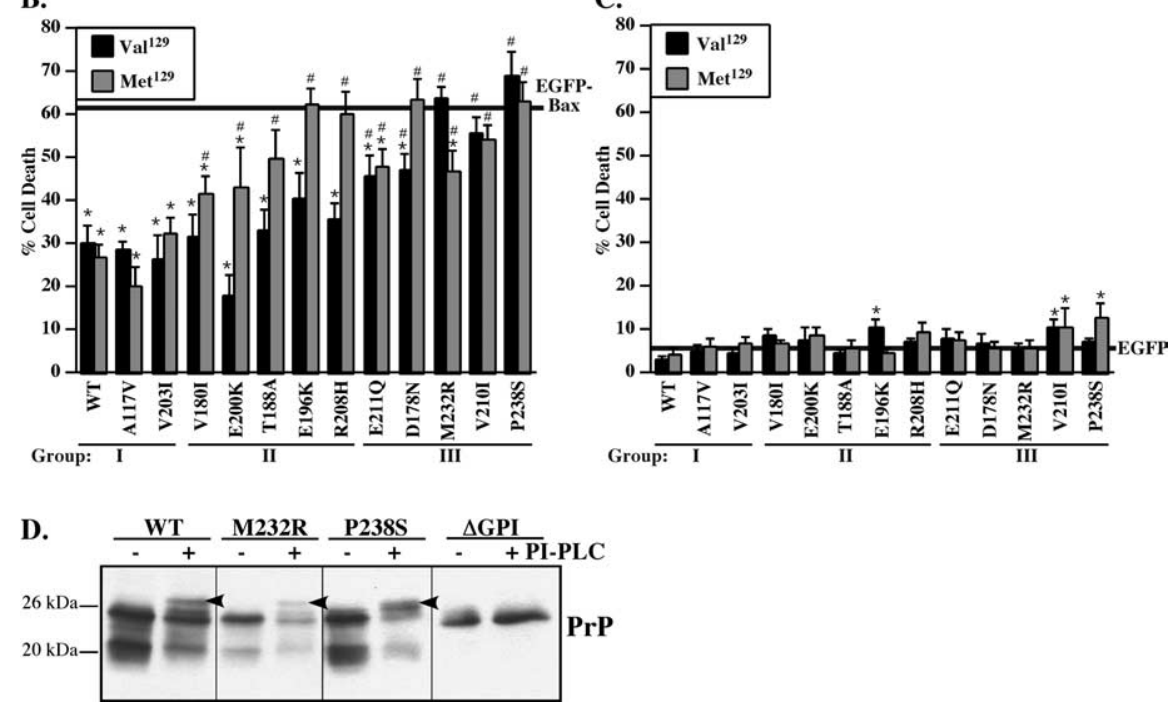

Figure 1. Anti-Bax function and toxicity of PrP mutants expressed in MCF-7 cells. $\boldsymbol{A}$, Schematic diagram showing various features of human prion protein, the relative positions of familial PrP mutations, and the polymorphic codon 129. TM, CHO, and S-S indicate the transmembrane domain, the glycosylation sites, and the disulfide bond, respectively. The first and second $\beta$-sheet ( $\beta 1$ and $\beta 2)$ and the three $\alpha$-helices $(\alpha \mathrm{A}, \alpha \mathrm{B}$, and $\alpha \mathrm{C})$ of PrP are indicated. The numbers represent the amino acids. $\boldsymbol{B}$, Percentage of cell death measured in MCF-7 cells transfected with pBud-EGFP-Bax alone (solid line) or transfected with pBudEGFP-Bax/PrP or PrP mutants carrying either a valine $\left(\mathrm{Val}^{129}\right)$ or a methionine (Met ${ }^{129}$ ) at codon 129. C, Percentage of cell death in MCF-7 cells transfected with pBud-EGFP (solid line) or pBud-EGFP/PrP and PrP mutants carrying either a valine $\left(\right.$ Val ${ }^{129}$ ) or a methionine (Met ${ }^{129}$ ) at the codon 129. For $\boldsymbol{B}$ and $\boldsymbol{C}$, data represent the mean \pm SEM of three independent experiments. At least 600 cells were counted for each condition. ${ }^{*} p<0.05$, statistically significant difference between pBud-EGFP and pBud-EGFP/ PrP-transfected cells or pBud-EGFP-Bax- and pBud-EGFP-Bax/PrP-transfected cells. ${ }^{\#} p<0.05$, statistically significant difference between pBud-EGFP-Bax/PrP and pBud-EGFP-Bax/PrP mutants. D, Western blot analyses of PrP with 3 F4 in codon Val ${ }^{129}$ pCep4 $\beta$-PrP-, pCep4 $\beta$-PrPM232R-, pCep4 $\beta$-PrPP238S-, or pCep4 $\beta$-PrP $\Delta$ GPI-transfected MCF-7 cell protein extracts treated without $(-)$ or with $(+)$ PI-PLC and deglycosylated with PNGase F. The arrow indicates a mobility shift as expected after removal of the GPI anchor.

Table 1. Identification of three groups of PrP mutants based on their protection against Bax-mediated cell death in MCF-7 cells

\begin{tabular}{|c|c|c|c|c|c|}
\hline & \multicolumn{2}{|c|}{ Protection against Bax } & \multicolumn{2}{|c|}{ Amino acid } & \multirow[b]{2}{*}{ Secondary structure } \\
\hline & $\mathrm{Val}^{129}$ & $\operatorname{Met}^{129}$ & Polarity & Charge & \\
\hline \multicolumn{6}{|l|}{ Group I } \\
\hline WT & Yes & Yes & - & - & $\beta$-Sheet 1 \\
\hline A117V & Yes & Yes & - & - & TM \\
\hline V2031 & Yes & Yes & - & - & $\alpha$-Helix C \\
\hline \multicolumn{6}{|l|}{ Group II } \\
\hline V180l & Yes & Partial & - & - & $\alpha$-Helix B \\
\hline E200K & Yes & Partial & - & + & $\alpha$-Helix C \\
\hline T188A & Yes & Partial & + & - & $\alpha$-Helix B \\
\hline E196K & Yes & No & - & + & Between $\alpha$-helix B/C \\
\hline $\mathrm{R} 208 \mathrm{H}$ & Yes & No & - & - & $\alpha$-Helix C \\
\hline \multicolumn{6}{|l|}{ Group III } \\
\hline E2110 & Partial & Partial & - & + & $\alpha$-Helix C \\
\hline D178N & Partial & No & - & + & $\alpha$-Helix B \\
\hline$M 232 R$ & No & Partial & + & + & GPI anchor signal \\
\hline V210I & No & No & - & - & $\alpha$-Helix C \\
\hline P238S & No & No & + & - & GPI anchor signal \\
\hline
\end{tabular}

Change in the polarity or the charge of the amino acid in the PrP mutation are indicated, using + if there is a change and - if there is no change. The location of the substituted amino acid in the secondary structure of $\mathrm{PrP}$ is provided. TM, Transmembrane domain. 

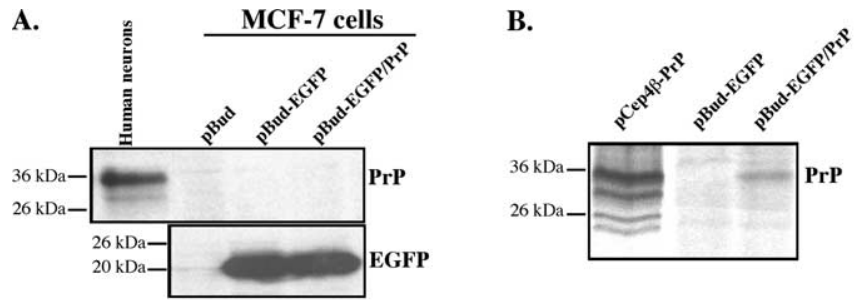

C.

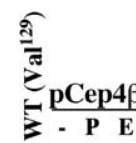

D.

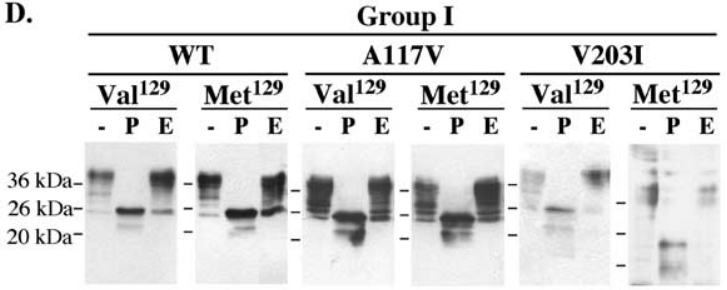

Group II

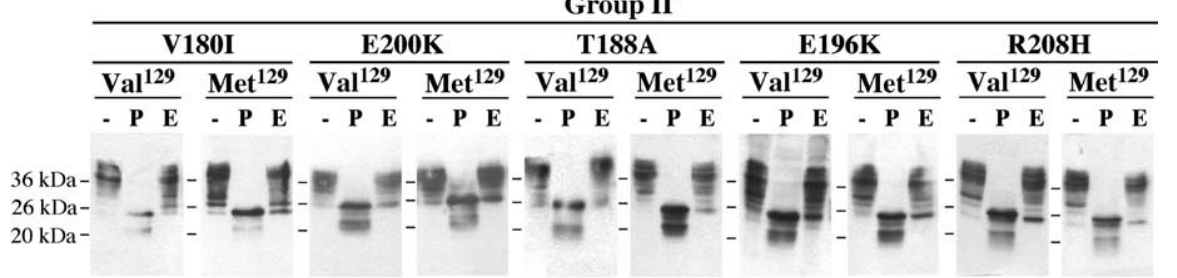

Group III

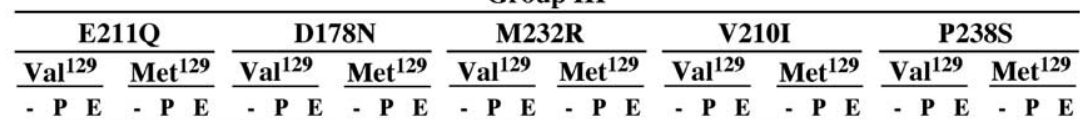
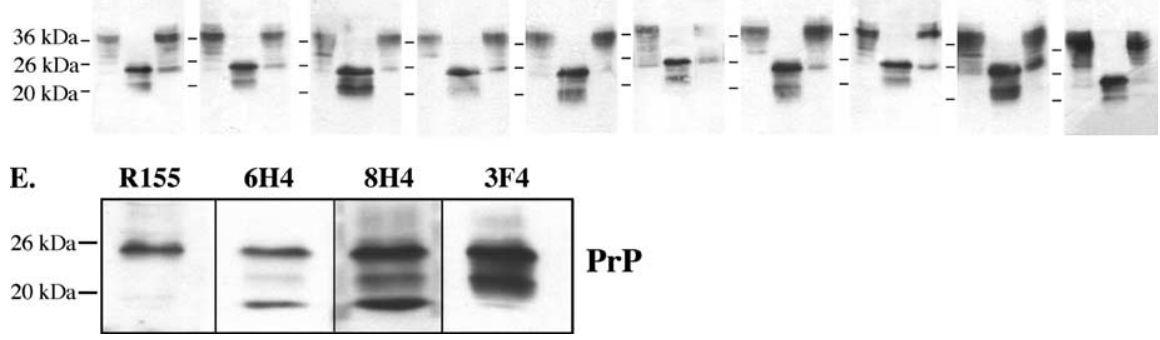

Figure 2. Expression and glycosylation status of PrP mutants in MCF-7 cells. $A$, Western blot analyses of PrP (3F4) and EGFP in MCF-7 cells transfected with pBudCE4.1 vector (pBud), pBud-EGFP, and pBud-EGFP/Nal ${ }^{129}$ WT PrP (pBud-EGFP/PrP). B, Autoradiogram of PrP immunoprecipitated from metabolically labeled MCF-7 cells transfected with pCep4 $\beta$-Val ${ }^{129} \mathrm{WT}$ PrP, pBudEGFP, and pBud-EGFP/PrP. C, Western blot of PrP with $3 F 4$ of protein extracts treated without enzyme ( - ), with PNGase F (P), or with Endo $H$ (E) from pCep $4 \beta$ (Control) and pCep $4 \beta$-PrPT183A-transfected cells (right). D. Western blot of PrP with $3 F 4$ of protein extracts treated without enzyme (-), with PNGase F (P), or with Endo H (E) from pCep4 $\beta$-PrP (WT) or pCep4 $\beta$-PrP mutanttransfected cells. E, Western blot of PrP in PNGase F-treated protein extracts from pCep4 $\beta$-PrP Val ${ }^{129}$-transfected cells with R155, $6 \mathrm{H} 4,8 \mathrm{H} 4$, or $3 F 4$ antibodies.

gated whether the mutations M232R and P238S result in proper GPI posttranslational processing because both lose the anti-Bax function despite the mutations being in a part of the PrP that should be removed in the mature protein. PI-PLC followed by deglycosylation treatments of protein extracts induces a mobility shift of WT PrP (Fig. 1D) as shown previously (Walmsley and Hooper, 2003). As expected, the control PrP lacking the GPI signal sequence ( $\Delta \mathrm{GPI})$ does not shift with the PI-PLC treatment. However, both the M232R and P238S PrP mutants undergo the same mobility shift as WT PrP, indicating that they have acquired the GPI anchor. Furthermore, the molecular weight of the deglycosylated M232R and P238S PrP mutants is identical to that of WT PrP, indicating that the signal peptides have been removed adequately. These results indicate that loss of function of these two PrP mutations is not attributable to the improper addition of the GPI anchor.
Expression, limited PK resistance, or posttranslational modifications of the PrP mutants do not account for the loss of anti-Bax function

Steady-state PrP levels or detergent solubility does not account for the loss of antiBax function in the mutants (supplemental Fig. 1, available at www.jneurosci.org as supplemental material). For example, Met ${ }^{129}$ V203I and $\mathrm{Val}^{129} \mathrm{E} 196 \mathrm{~K}$ transfected cells display lower levels of PrP but retain the anti-Bax function. Detergent insolubility is not variable among groups I, II, and III. PrP or PrP mutants in the first and second groups are very sensitive to limited PK digestion except for the $\mathrm{Met} / \mathrm{Val}{ }^{129} \mathrm{~A} 117 \mathrm{~V}$ and $\mathrm{R} 208 \mathrm{H}$ mutants (supplemental Fig. 2, available at www.jneurosci.org as supplemental material). Both Val ${ }^{129}$ and Met $^{129}$ PrP mutants in the third group are resistant to limited PK digestion. Therefore, some PrP mutants that retain or lose anti-Bax activity have limited PK resistance, whereas some PrP mutants with no anti-Bax activity are sensitive to $\mathrm{PK}$. Therefore, the resistance or sensitivity of $\operatorname{PrP}$ mutants to limited PK digestion does not correlate with the antiBax function.

We then investigated whether posttranslational modifications could explain the loss of anti-Bax function in the PrP mutants. Glycosylation of $\operatorname{PrP}$ occurs at Asn $^{181}$ and Asn ${ }^{197}$ (Endo et al., 1989). Unfortunately, whereas EGFP expression is easily detected by Western blotting of pBud-EGFP/PrP-transfected MCF-7 cells, PrP is not (Fig. 2A). Only very low levels of $\operatorname{PrP}$ can be seen by immunoprecipitation of metabolically labeled pBudEGFP/PrP-transfected MCF-7 cells (Fig. $2 B$ ). However, the level of PrP is easily detected in MCF-7-transfected cells with the episomal pCep $4 \beta-\operatorname{PrP}$ construct, which yields $50-100$ copies of the cDNA per cell (Groger et al., 1989). To facilitate biochemical detection of the transfected mutant PrPs, we expressed the mutant PrPs under the CMV promoter of the pCep $4 \beta$ construct. PrP is absent in pCep $4 \beta$ transfected MCF-7 cells, confirming that the immunoreactive PrP proteins are from the exogenous expression of PrP mutants (Fig. 2C). As a control, the ER-retained T183A PrP is almost completely sensitive to Endo $\mathrm{H}$ removal of high mannose sugars, as expected (Kiachopoulos et al., 2005). Val/Met ${ }^{129}$ WT PrP migrate mostly as mature glycosylated forms of PrP and are completely deglycosylated by PNGase F, resulting in 25 and $23 \mathrm{kDa}$ proteins (Fig. $2 D$ ). The $25 \mathrm{kDa}$ protein is consistent with the deglycosylated or immature form of PrP, whereas the $23 \mathrm{kDa}$ likely represents a N-terminally cleaved product of deglycosylated $\operatorname{PrP}$ because the N-terminal-directed R155 PrP antibody does not recognize the $23 \mathrm{kDa}$ protein (Fig. $2 E$ ). The immature high mannose glycosylated form of PrP represents only a small fraction of the total PrP, and this protein, migrating at $\sim 30 \mathrm{kDa}$, 
shifts to $25 \mathrm{kDa}$ during treatment with Endo H (Fig. 2D). Similarly, all PrP mutants, except $\mathrm{Met} / \mathrm{Val}^{129}$ V203I, $\mathrm{Val}^{129} \mathrm{M} 232 \mathrm{R}$, and $\mathrm{Met}^{129} \mathrm{P} 238 \mathrm{~S}$, are sensitive to Endo $\mathrm{H}$ as indicated by the increase in the $25 \mathrm{kDa}$ protein. All PrP mutants, with variations in the abundance of the glycosylated forms, generate the 23 and $25 \mathrm{kDa}$ proteins with PNGase F treatment. This confirms previous observations with the V203I, V210I, and E211Q PrP mutants (Vetrugno et al., 1999; Mishra et al., 2003). However, in $\mathrm{Met}^{129} \mathrm{~A} 117 \mathrm{~V}$, Met ${ }^{129} \mathrm{~T} 188 \mathrm{~A}, \quad$ Met/Val ${ }^{129} \mathrm{E} 196 \mathrm{~K}, \quad$ Met/ $\mathrm{Val}^{129} \mathrm{R} 208 \mathrm{H}, \quad \mathrm{Val}^{129} \mathrm{M} 232 \mathrm{R}, \quad$ and Met ${ }^{129} \mathrm{P} 238 \mathrm{~S}$, the 25 and $23 \mathrm{kDa}$ proteins migrate as doublets, indicating additional changes, possibly truncation of these $\mathrm{PrP}$ mutant proteins. These results indicate that, despite some slight differences, glycosylation of the PrP mutants cannot account for the loss of anti-Bax function.

\section{The levels of CyPrP generated by PrP mutants correlate with the anti-Bax function}

CyPrP prevents Bax-mediated cell death in human neurons (Roucou et al., 2003); therefore, we investigated whether PrP mutations affect the levels of CyPrP (Fig. 3). pCep $4 \beta-\operatorname{PrP}$ or PrP mutanttransfected MCF-7 cells were treated with BFA and epoxomycin to inhibit proteasomal degradation and were submitted to subcellular fractionations into membrane and cytosolic fractions, as done previously (Roucou et al., 2003). Unfortunately, BFA and epoxomycin treatment of MCF-7 cells results in the expression of endogenous human $\operatorname{PrP}$ (Fig. 3A). Therefore, we switched to mouse N2a cells because the endogenous mouse PrP is not recognized by the 3F4 antibody. The presence of mitochondrial Hsp70 and cytochrome $c$ only in the membranes and the presence of Tau protein mainly in the cytosol confirm the purity of the subcellular fractions (Fig. $3 B$ ). In untreated cells, $\operatorname{PrP}$ is detected only in the membrane subcellular fraction. As shown previously, in the presence of epoxomycin and BFA, immature PrP is detected in the cytosol and membranes. The size of the CyPrP is consistent with retrotranslocated PrP lacking both the $\mathrm{N}$ - and C-terminal signal peptides because the deglycosylated CyPrP comigrates with recombinant human $\mathrm{PrP}_{23-231}$ (Fig. 3C). In group I, the ratio of $\mathrm{CyPrP}$ over membrane $\mathrm{PrP}$ is equivalent or tends to be slightly higher than that of WT PrP (Fig. 3D). Group II $\mathrm{Val}^{129} \mathrm{PrP}$ mutants that retain completely the anti-Bax function have the same level of CyPrP than WT PrP. In contrast, Met ${ }^{129} \mathrm{PrP}$ mutants that partially or completely lose the anti-Bax function have significantly decreased levels of CyPrP. Group III $\mathrm{Val}^{129}$ and $\mathrm{Met}^{129} \mathrm{PrP}$ mutants that partially or completely lose anti-Bax function all have significantly lower levels of CyPrP. The loss of anti-Bax function for PrP mutants correlates well with the decrease of CyPrP (Fig. 3E). These results indicate that the reduc-
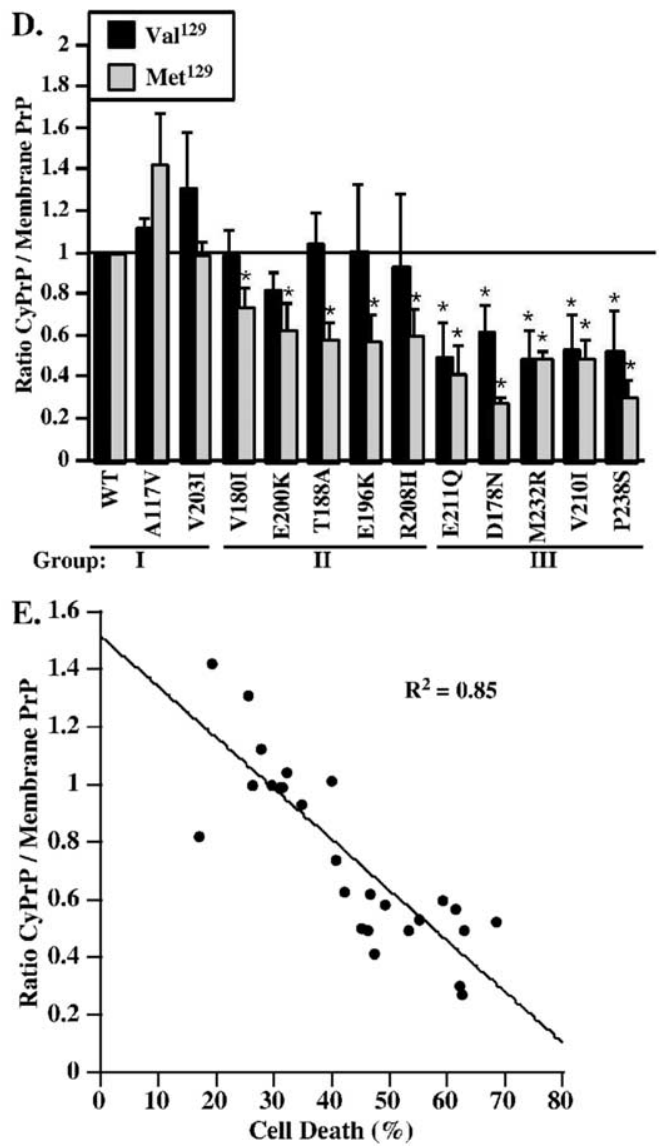

PrP

Figure 3. Analysis of PrP mutants located in the cytosol. $\boldsymbol{A}$, Western blot of PrP with $3 \mathrm{~F} 4$ in protein extracts from pCep4 $\beta(-)$ with 3F4, mitochondrial Hsp70 (mHsp70), cytochrome c (Cyt c), or Tau in proteins from membrane and cytosolic fractions of pCep4 $\beta$-PrP Val ${ }^{129}$-transfected N2a cells treated or untreated (control) with epoxomycin and BFA. Equal amounts of membrane carrying either a valine $\left(\mathrm{Val}^{129}\right.$ ) or a methionine $\left(\mathrm{Met}^{129}\right.$ ) at codon 129. The data represent the mean \pm SEM of three independent

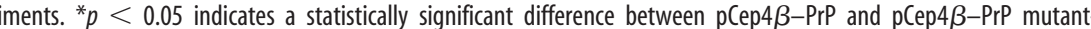
transfected cells. $\boldsymbol{E}$, Correlation between the anti-Bax function of PrP mutants in MCF-7 cells and CyPrP level. The correlation is statistically significant $(p<0.0001)$.

tion or loss of CyPrP from PrP mutants may be responsible for the deficit in anti-Bax function.

The inability of PrP mutants to generate normal levels of CyPrP is not accompanied with abnormal cell surface GPIanchored PrP levels

To examine whether there are other trafficking problems with the mutant PrPs, we looked at cell surface PrP. As observed previously (Winklhofer et al., 2003; Kiachopoulos et al., 2005), PI-PLC treatment of the pCep $4 \beta-\mathrm{PrP}$-transfected MCF-7 cells releases significant amounts of the WT or mutant PrPs (Fig. 4A). There is no consistent difference between group I, II, or III or between $\mathrm{Val}^{129}$ and Met ${ }^{129} \mathrm{PrP}$ mutants, which indicates that the defect in making $\mathrm{CyPrP}$ is not accompanied by a problem with trafficking to the cell surface.

Similarly, secretion of PrP is not affected. In primary human neuron cultures, PrP is secreted into the media (Bounhar et al., 2001) as is WT or mutant PrPs from pCep $4 \beta$-transfected MCF-7 cells (Fig. $4 B$ ). Both the $25 \mathrm{kDa}$ immature and $36-40 \mathrm{kDa}$ mature glycosylated forms of PrP are secreted. However, compared with 
A.

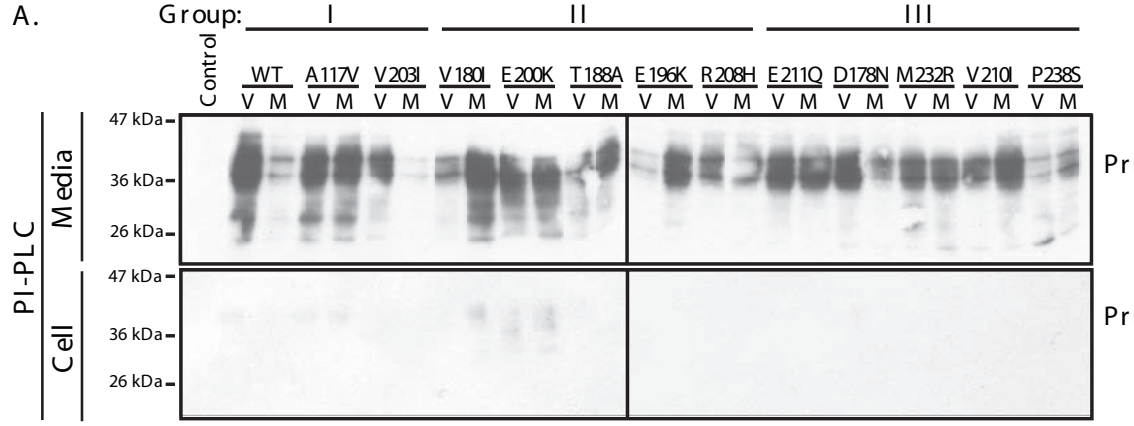

$$
\text { Group: }
$$
। 11

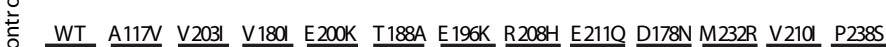
¿े $\frac{W T}{V M} \frac{A 11 N}{V M} \frac{V 203}{V M} \frac{V 180}{V M} \frac{E 200 K}{V M} \frac{T 180 A}{V M} \frac{E M}{V M} \frac{R}{V M} \frac{D 190 K}{V M} \frac{R M}{V M M}$

B.

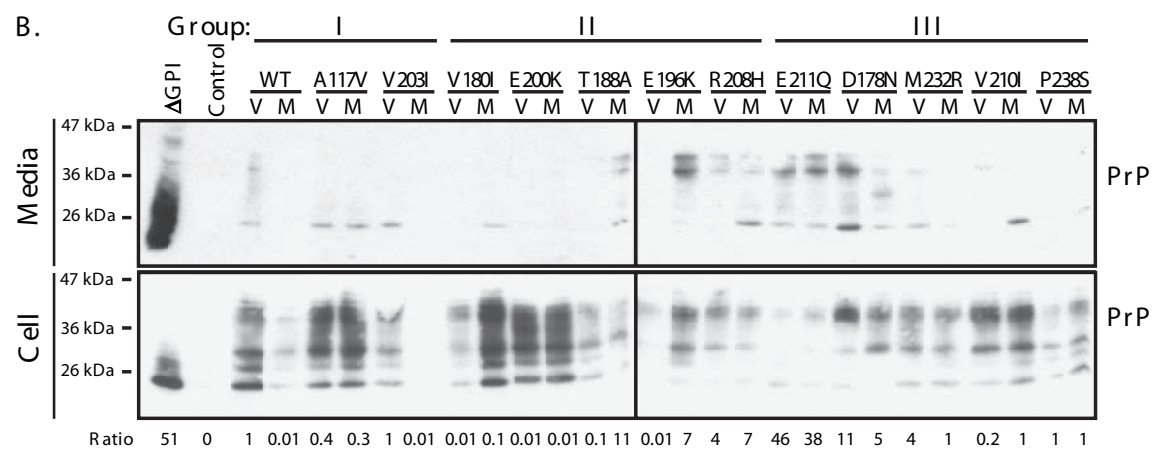

Figure 4. PrP mutants are GPI anchored. $\boldsymbol{A}$, Western blot of PI-PLC-treated pCep $4 \beta$ - (Control), pCep4 $\beta$-PrPVal ${ }^{129}$ - (V), or Met $^{129}(\mathrm{M})$ and pCep4 $\beta$-PrP mutant-transfected MCF-7 cellular and released PrP with 3F4. B , Western blot of secreted and cellular PrP from PrP $\Delta$ GPI, empty vector (Control), Val ${ }^{129}$ (V), or Met ${ }^{129}$ (M) WT and mutant PrP-transfected MCF-7 cells. Ratio corresponds to the ratio of secreted PrP over cellular PrP.

the secretion of the positive control PrP lacking the GPI signal sequence $(\Delta \mathrm{GPI}), \operatorname{PrP}$ and $\operatorname{PrP}$ mutants are weakly secreted. The ratios of secreted $\operatorname{PrP}$ over cellular PrP indicates that Met ${ }^{129}$ T188A, E196K, and R208H, and the Val/Met ${ }^{129}$ E211Q and D178N mutants are more abundantly secreted relative to WT PrP. Whether PrP is released by an endogenous lipase or is actually secreted without attaching to the cell surface is not clear. However, the level of PrP secretion does not correlate with the anti-Bax function because ratios vary from 0.01 to 46 in group III mutants, in which all have partially or completely lost anti-Bax function. Together, these results indicate that the loss of anti-Bax function in PrP mutants is not explained by the loss of cell surface GPI-anchored PrP or by altered secretion of PrP.

\section{Cotransfection of PrP mutants with wild-type or mutant CyPrP, but not with wild-type full-length PrP, rescues the loss of anti-Bax function in PrP mutants}

To determine whether the decrease of CyPrP explains the loss of anti-Bax function in PrP mutants, we coexpressed CyPrP with all PrP mutants that have partially or completely lost the anti-Bax function. For this, we cotransfected MCF-7 cells with pBudEGFP-Bax/PrP mutants and pCep4 $\beta-$ CyPrP (Fig. 5). CyPrP confers anti-Bax function to all pBud-EGFP-Bax/PrP mutanttransfected cells. To determine whether the PrP mutation also affect the anti-Bax function, we repeated the rescue experiment with pCep $4 \beta-\mathrm{CyPrP}$ mutants carrying the same mutation as that of the pBud-EGFP-Bax/PrP mutant. CyPrP mutant expression was confirmed (supplemental Fig. 3, available at www.jneurosci.org as supplemental material). Two of the CyPrP mutants (M232R and P238S) were expressed with the GPI signal peptide because the mutations are present in this domain. Again, all mutant CyPrPs rescue the anti-Bax activity (Fig. 5).

Finally, we attempted to rescue the loss of anti-Bax function in III

PrP mutants by cotransfecting with pCep $4 \beta-P r P$. Unexpectedly, wild-type PrP expression does not rescue the loss of anti-Bax function in any of the pBudEGFP-Bax/PrP mutant-transfected MCF-7 cells.

Together, these results indicate that the loss of CyPrP is responsible for the loss of anti-Bax function in PrP mutants. Furthermore, the inability of full-length WT $\mathrm{PrP}$ to rescue suggests that the PrP mutants have a dominant effect on the ability of wild-type PrP to retrotranslocate into the cytosol.

\section{The loss of anti-Bax function in PrP mutants is more prominent in human neurons than in MCF-7 cells}

We next investigated whether the mutant PrPs retain the anti-Bax function in primary cultures of human neurons. EGFPBax expression induces cell death within $24 \mathrm{~h}$ (Fig. 6A). As seen in MCF-7 cells, WT PrP inhibits EGFP-Bax-mediated cell death by $50 \%$. The anti-Bax function of $\operatorname{PrP}$ is lost in $83 \%$ of $\mathrm{PrP}$ mutants. All $\mathrm{Met}^{129} \mathrm{PrP}$ mutants and $67 \%$ of $\mathrm{Val}^{129}$ PrP mutants partially or completely lose their anti-Bax function. The codon 129 of endogenously expressed PrP in human neurons does not affect the anti-Bax function of PrP mutants (supplemental Fig. 4, available at www.jneurosci.org as supplemental material). In group I, only Met/Val ${ }^{129} \mathrm{WT}$ PrP protects against Bax. In group II, Val ${ }^{129}$ A117V, V203I, T188A, and E200K mutants retain protection against Bax, whereas the Met ${ }^{129}$ counterparts lose this protection. In group III, both $\mathrm{Val}^{129}$ and $\mathrm{Met}^{129}$ D178N, R208H, E211Q, V180I, E196K, V210I, M232R, and P238S PrP mutants lose anti-Bax function. Only three mutants partially retain function: the Met ${ }^{129} \mathrm{D} 178 \mathrm{~N}$, the $\mathrm{Val}{ }^{129} \mathrm{R} 208 \mathrm{H}$, and the $\mathrm{Val}^{129} \mathrm{E} 211 \mathrm{Q}$. The loss of anti-Bax function by PrP mutants is not associated with a change in either the polarity or charge of the substituted amino acids (Table 2). Furthermore, the position of the PrP mutations in the secondary structure of the protein does not correlate with the loss of anti-Bax function.

In contrast to the MCF-7 cells, human neurons were more susceptible to the mutant PrP expressions. The background level of cell death in nontransfected and EGFP-transfected human neurons is $15 \pm 3$ and $16 \pm 3 \%$, respectively. Therefore, EGFP is not toxic to these neurons. The Met ${ }^{129} \mathrm{~T} 188 \mathrm{~A}, \mathrm{E} 200 \mathrm{~K}, \mathrm{R} 208 \mathrm{H}$, E211Q, V180I, E196K, M232R, and P238S and the Val ${ }^{129}$ D178N, R208H, E211Q, M232R, and P238S mutants exhibit low but statistically significant cytotoxicity (Fig. 6B). However, as observed in MCF-7 cells, cytotoxicity does not correlate with the loss of the anti-Bax function.

Because it is not possible to transfect the human neurons with high efficiency, these studies are restricted to single-cell analyses. However, we did perform rescue experiments in three PrP mutants of the third group that completely lose the anti-Bax function. pCep4 $\beta-$ CyPrP reduces cell death in pBud-EGFP-Bax/PrP V180I Met ${ }^{129}$-, E196K Met ${ }^{129}$-, and V210I Val ${ }^{129}$-transfected human neurons, but the difference does not reach statistical significance for pBud-EGFP-Bax/PrP V180I Met ${ }^{129}$ (Fig. 6C). As seen in MCF-7 cells, all CyPrP mutants rescue against the loss of 


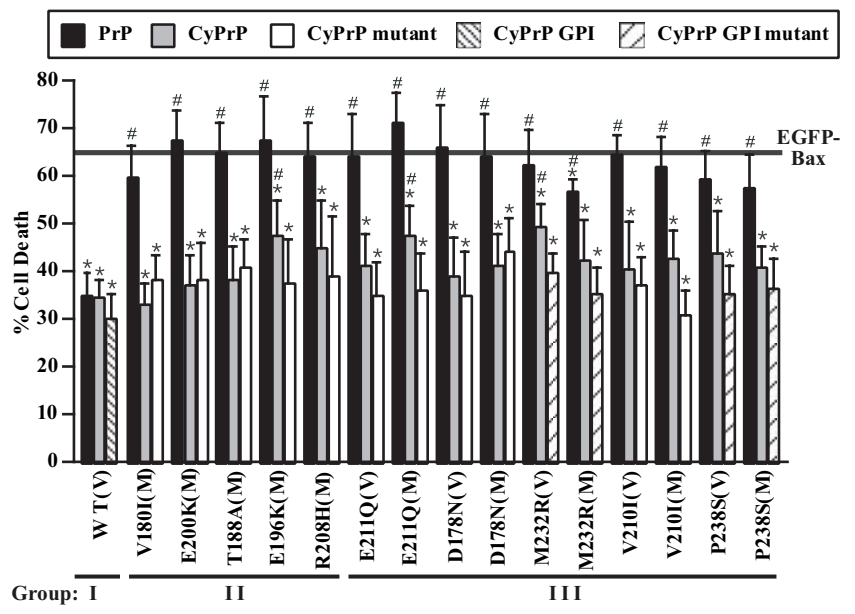

Figure 5. CyPrP and CyPrP mutants, but not full-length WT PrP, rescue the loss of anti-Bax function of full-length PrP mutants. Percentage of cell death in MCF-7 cells transfected with two constructs with a ratio of 1:3 of pBud-EGFP-Bax:pCep $4 \beta$ (solid line), pBud-EGFP-Bax/PrP Val ${ }^{129}$ (WT) or pBud-EGFP-Bax/PrP mutants (as indicated in $x$-axis):pCep4 $\beta$-PrP Val ${ }^{129}$ (PrP, black bar), pBud-EGFP-Bax/PrP Val ${ }^{129}$ or pBud-EGFP-Bax/PrP mutants:pCep4 $\beta$-CyPrP Val $^{129}$ (CyPrP, gray bar), pBud-EGFP-Bax/PrP Val ${ }^{129}$ or pBud-EGFP-Bax/PrP mutants: pCep4 $\beta$-CyPrP mutant Val ${ }^{129}$ (CyPrP mutant, white bar), pBud-EGFP-Bax/PrP Val ${ }^{129}$ or pBud-EGFP-Bax/PrP mutants:pCep4 $\beta$-CyPrP GPI, or pBud-EGFP-Bax/PrP Val ${ }^{129}$ or pBudEGFP-Bax/PrP mutants:pCep4 $\beta$-CyPrP GPI mutants. Mutations in pCep4 $\beta$-CyPrP and $\mathrm{pCep} 4 \beta$-CyPrP GPI are identical to that tested in the pBud construct (indicated in $x$-axis). PrP mutants carry either a valine $(V)$ or a methionine (M) at codon 129. The WT PrP shown here has a Val ${ }^{129}$ codon, and the results were similar in PrP Met ${ }^{129}$. Data represent the mean \pm SEM of three independent experiments. At least 400 cells were counted for each condition. ${ }^{*} p<0.05$, statistically significant difference between pBud-EGFP-Bax-and pBud-EGFP-Bax/PrP- or PrP mutant-transfected cells. ${ }^{p} p<0.05$, statistically significant difference between $\mathrm{pBud-EGFP-}$ Bax/PrP and pBud-EGFP-Bax/PrP mutant-transfected cells.

anti-Bax function, but wild-type full-length PrP cannot rescue the loss of anti-Bax function in these PrP mutants. These results show that, as in MCF-7 cells, CyPrP or CyPrP mutants rescue human neurons from the loss of anti-Bax function of PrP mutants, and the effect is dominant. This likely explains why the PrP mutants lose their anti-Bax function despite high expression of endogenously expressed PrP in these cells.

\section{Discussion}

We show here that most of the familial PrP mutants exhibit a significant loss of the PrP anti-Bax function in human neurons and MCF-7 cells. The ability of mutants to protect against Baxmediated cell death is divided into three groups: (1) group I, retention of anti-Bax function in both $\mathrm{Val}^{129}$ and Met ${ }^{129} \mathrm{mu}-$ tants; (2) group II, retention of anti-Bax function only in $\mathrm{Val}^{129}$ mutants; and (3) group III, reduction or loss of anti-Bax function in both $\mathrm{Val}^{129}$ and Met ${ }^{129}$ mutants. The loss of anti-Bax function in $\mathrm{PrP}$ mutants correlates entirely with a significant decrease in the production of CyPrP. CyPrP arises from incomplete translocation into the endoplasmic reticulum or retrotranslocation from the endoplasmic reticulum (Ma and Lindquist, 2001; Roucou et al., 2003; Rane et al., 2004). Incomplete translocation results in a PrP that lacks the $\mathrm{N}$-terminal signal peptide but retains the C-terminal GPI anchor signal peptide. Here, we find that the CyPrP does not contain the N-terminal or GPI signal peptides and thus is generated through retrotranslocation. The CyPrP has been shown to be cytotoxic in mouse neuroblastoma N2a cells and in cerebellar granular neurons, possibly through aberrant interaction with membrane lipids (Ma and Lindquist, 2001, 2002; Wang et al., 2006). The decrease in retrotranslocated CyPrP is unexpected because familial $\operatorname{PrP}$ mutants are associated with neuronal degeneration and cell death in human disease, a condition that could have been initiated by CyPrP cytotoxicity. However, $\mathrm{CyPrP}$ is not toxic and protects human neurons in primary cultures (Roucou et al., 2003) and MCF-7 cells (D. T. S. Lin and A. C. LeBlanc, unpublished observations) against Bax-mediated cell death. In addition, CyPrP is not toxic to a number of other human neuroblastoma cells (Roucou et al., 2003). Here, we show that wild-type CyPrP rescues the loss of anti-Bax function in $\mathrm{PrP}$ mutants. Therefore, CyPrP is essential to PrP anti-Bax function. Furthermore, the mutant CyPrP also rescue against the loss of anti-Bax function in PrP mutants, indicating that the mutations in PrP do not alter the structural entity responsible for the antiBax function. Therefore, we conclude that these PrP mutants lose the ability to prevent Bax-mediated cell death because they cannot generate enough CyPrP.

Exactly how all of these PrP mutations alter retrotranslocation of PrP is not clear. The change in the charge, the polarity, or the position of the substituted amino acids in mutant PrPs do not correlate with the loss of anti-Bax function or the production of CyPrP. It is generally assumed that PrP mutations alter the conformation of the PrP. D178N, V180I, R208H, and V210I amino acid substitutions thermodynamically destabilize the PrP (Riek et al., 1998; Liemann and Glockshuber, 1999; Apetri et al., 2004). However, not all PrP mutants are affected in this way. Moreover, mutant PrPs, such as D178N, possess misfolded protein characteristics (Lehmann and Harris, 1996). Interestingly, even the $\mathrm{M} 232 \mathrm{R}$ and $\mathrm{P} 238 \mathrm{~S}$ mutations, which are posttranslationally removed during GPI anchor addition, have reduced CyPrP levels. These results indicate that the $\mathrm{C}$ terminus of $\mathrm{PrP}$ regulates retrotranslocation of $\mathrm{PrP}$ before $\mathrm{PrP}$ is completely processed in the endoplasmic reticulum. Furthermore, the codon 129 polymorphism regulates retro-translocation because in group II, Val ${ }^{129}$ containing mutants have normal levels of CyPrP and retain their anti-Bax function, whereas Met ${ }^{129}$ containing mutants have reduced CyPrP levels and partially or completely lose the anti-Bax function. Relative to $\mathrm{Val}^{129}$, the $\mathrm{Met}^{129}$ increases the ability of PrP to fold with a higher $\beta$-sheet content and to oligomerize (Tahiri-Alaoui et al., 2004). Therefore, it is likely that codon 129 and familial mutations slightly alter the conformation of $\operatorname{PrP}$, thus resulting in altered posttranslational trafficking.

We also find that the mutant PrPs do not accumulate into the endoplasmic reticulum, are normally glycosylated, and accumulate at the cell surface as GPI-anchored proteins. These results suggest that the mutant PrPs escape the normal regulatory checkpoint for misfolded proteins, which constitutes $10 \%$ of newly synthesized WT PrP (Yedidia et al., 2001). Because many PrP mutants resist limited PK digestion, the mutants are likely misfolded. Cell surface PrP has been shown to induce several beneficial signaling transduction pathways (for review, see Roucou et al., 2004; Roucou and LeBlanc, 2005). The accumulation of these misfolded proteins could be detrimental to the normal function of PrP at the cell surface of the neurons.

Whereas wild-type or mutant CyPrP can rescue the anti-Bax function, the full-length wild-type $\operatorname{PrP}$ cannot rescue. This indicates that the mutant PrPs have a dominant effect with regards to retrotranslocation of $\mathrm{PrP}$ into the cytosol. The results explain why there is a loss of $\operatorname{PrP}$ anti-Bax function in PrP mutanttransfected primary cultures of human neurons, which express relatively high levels of endogenous normal PrP. The results are also consistent with the autosomal dominant nature of familial PrP mutations.

The retention of protection with the $\mathrm{Val}^{129}$ allele in group II is 


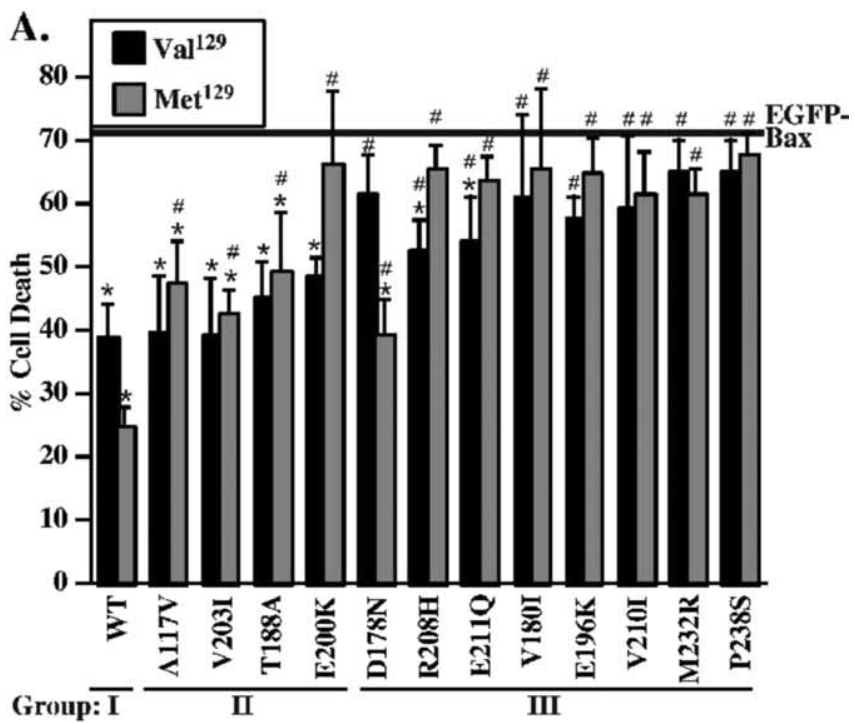

B.
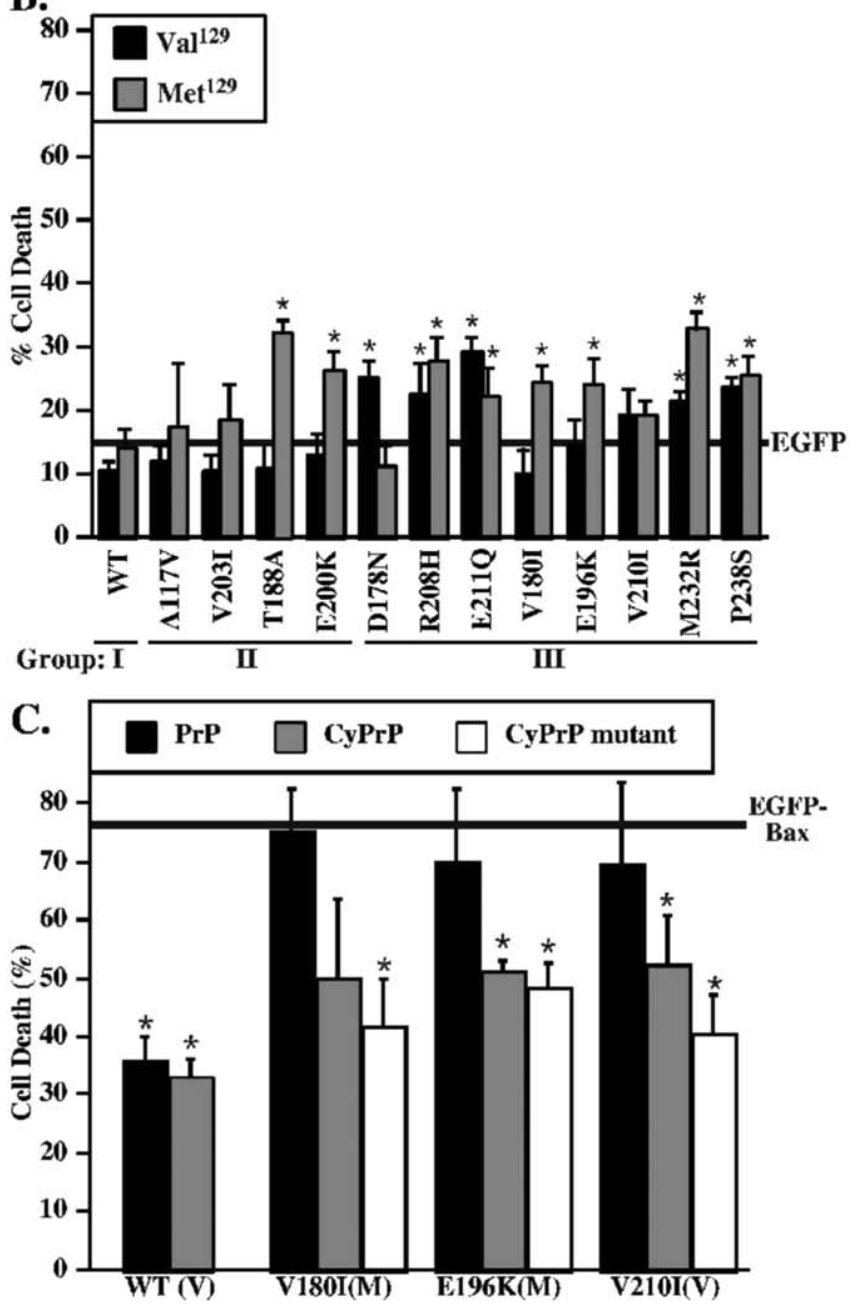

Figure 6. Anti-Bax function, toxicity, and rescue of anti-Bax function in human neurons transfected with PrP mutants. $\boldsymbol{A}$, Percentage of cell death in human neurons transfected with pBud-EGFP-Bax alone (solid line) or transfected with pBud-EGFP-Bax/PrP or PrP mutants carrying either a valine $\left(V_{a l}{ }^{129}\right)$ or a methionine $\left(\right.$ Met $^{129}$ ) at codon 129. Data represent the mean \pm SEM of three independent experiments. At least 150 cells were counted for each condition. ${ }^{*} p<0.05$, statistically significant difference between pBud-EGFP-Bax and pBudEGFP-Bax/PrP. ${ }^{\#} p<0.05$, statistically significant difference between pBud-EGFP-Bax/PrPand pBud-EGFP-Bax/PrP mutant-transfected cells. $\boldsymbol{B}$, Percentage of cell death in human neurons induced by EGFP (solid line) or EGFP expressed with WT or mutant PrP carrying either a consistent with observations that show a protective effect of $\mathrm{Val}^{129}$ against scrapie infections (Wadsworth et al., 2004). Our results in human neurons showing abrogation of anti-Bax function in all Met ${ }^{129} \mathrm{PrP}$ mutants are also consistent with the observations that individuals homozygous for methionine are more susceptible to develop a prion disease (Kovacs et al., 2005). Interestingly, all CJD human familial mutations encode a Met ${ }^{129}$ on the mutant allele. In addition, D178N and E200K mutations are also found with a Val ${ }^{129}$ mutant allele (Hoque et al., 1996; Windl et al., 1999; Peoc'h et al., 2000; Kovacs et al., 2005). Codon 129 strongly regulates the phenotypic manifestation of CJD ( $\mathrm{Val}^{129}$ ) and FFI (Met ${ }^{129}$ ) associated with the D178N mutation and the prion disease linked to the E200K mutation (Goldfarb et al., 1992; Hainfellner et al., 1999). Moreover, codon 129 polymorphism affects the type of pathological PrP in genetic prion diseases and, in some cases, the age of onset (Baker et al., 1991; Monari et al., 1994; Gambetti et al., 2003; Kovacs et al., 2005). Our observations show the additional influence of codon 129 polymorphism on the retrotranslocation and anti-Bax function of PrP mutants.

We confirm that the loss of anti-Bax function also occurs in human neurons. However, the loss is more prominent in human neurons than in MCF-7 cells. The Met/Val ${ }^{129} \mathrm{~A} 117 \mathrm{~V}$ and V203I group I mutations that retain protection against Bax in MCF-7 cells shift to group II in human neurons. Moreover, group II mutations Val ${ }^{129}$ V180I, E196K, and R208H that retain function in MCF-7 cells shift to group III in human neurons. One possible explanation for this difference is that the mutant PrPs are more cytotoxic to human neurons than MCF-7 cells. Unfortunately, it is impossible to study in these human neurons the level of CyPrP to determine whether it is lower in all of the mutants because primary cultures of human neurons are highly resistant to infections or transfections and ballistic transfection into the human neurons occurs at very low transfection efficiency and limits us to single-cell analyses. However, we show by cotransfection experiments that $\mathrm{CyPrP}$ and $\mathrm{CyPrP}$ mutants, but not WT full-length $\mathrm{PrP}$, also rescue the anti-Bax function of PrP mutants in human neurons. These results indicate that $\mathrm{CyPrP}$ deficits are also responsible for the loss of anti-Bax function in human neurons.

Neuronal apoptosis is observed in FFI and familial CJD (Gray et al., 1999; Ferrer, 2002). Because clinical symptoms are manifested during aging in familial cases, it is possible that the loss of anti-Bax prion function contributes to age-dependent Baxmediated apoptosis. Several age-dependent insults, such as oxidative stress and endoplasmic reticulum stress, activate Bax (Savory et al., 1999; Keller et al., 2002; Phaneuf and Leeuwenburgh, 2002). Interestingly, the universal anti-Bax inhibitor protein Bcl-2 decreases in the aging CNS (Merry et al., 1994). Because $\mathrm{Bcl}-2$ has wide-ranging effects on many proapoptotic proteins, it is possible that $\operatorname{PrP}$, which is quite specific against $\mathrm{Bax}$ (Roucou et al., 2005), replaces the broader Bcl-2 protein for a more focused

valine $\left(\right.$ Val $\left.{ }^{129}\right)$ or a methionine $\left(\right.$ Met $\left.{ }^{129}\right)$ at codon 129 . Data represent the mean \pm SEM of three independent experiments. At least 150 cells were counted for each condition. ${ }^{*} p<0.05$, statistically significant difference between pBud-EGFP- and pBud-EGFP/PrP- or PrP mutanttransfected cells. The codon 129 of endogenous PrP in human neurons is shown at supplemental Figure 4. C, Percentage of cell death in human neurons transfected with pBud-EGFP-Bax: pCep4 $\beta$ (solid line), pBud-EGFP-Bax/PrP Val ${ }^{129}$ (WT PrP) or pBud-EGFP-Bax/PrP mutant (indicated in $x$-axis):pCep4 $\beta$-PrP Val ${ }^{129}$ (PrP, black bar), pCep4 $\beta$-CyPrP Val ${ }^{129}$ (gray bar), or pCep4 $\beta$-CyPrP mutant (white bar). PrP mutants carry either a valine (V) or a methionine (M) at codon 129 . Data represent the mean \pm SEM of three independent experiments. At least 50 cells were counted for each condition. ${ }^{*} p<0.05$, statistically significant difference between pBudEGFP-Bax- and pBud-EGFP-Bax/PrP- or PrP mutant-transfected cells. 
effect against Bax-mediated cell death in the aging CNS. Therefore, it is possible that the loss of anti-Bax function in $\mathrm{PrP}$ mutants contributes to the loss of neurons in prion diseases.

In summary, we find that PrP mutants associated with familial prion diseases lose their anti-Bax function and that this loss of function is attributable to a deficit in generating CyPrP. The loss of the anti-Bax function in mutant PrPs may result in a higher susceptibility of neurons to agedependent Bax-mediated neuronal cell death in familial prion diseases. In addition, these results suggest that the mutant PrPs escape the retrotranslocation pathway normally responsible for removing misfolded protein. In these conditions, the accumulation of misfolded PrP could adversely affect neuronal function.
Table 2. Identification of three groups of PrP mutants based on their protection against Bax-mediated cell death in human neurons

\begin{tabular}{|c|c|c|c|c|c|}
\hline & \multicolumn{2}{|c|}{ Protection against $\mathrm{Bax}$} & \multicolumn{2}{|c|}{ Amino acid } & \multirow[b]{2}{*}{ Secondary structure } \\
\hline & $\mathrm{Val}^{129}$ & $\mathrm{Met}^{129}$ & Polarity & Charge & \\
\hline \multicolumn{6}{|l|}{ Group I } \\
\hline WT & Yes & Yes & - & - & $\beta$-Sheet 1 \\
\hline \multicolumn{6}{|l|}{ Group II } \\
\hline A117V & Yes & Partial & - & - & $\mathrm{TM}$ \\
\hline V203I & Yes & Partial & - & - & $\alpha$-Helix C \\
\hline T188A & Yes & Partial & + & - & $\alpha$-Helix B \\
\hline E200K & Yes & No & - & + & $\alpha$-Helix C \\
\hline \multicolumn{6}{|l|}{ Group III } \\
\hline D178N & No & Partial & - & + & $\alpha$-Helix B \\
\hline $\mathrm{R} 208 \mathrm{H}$ & Partial & No & - & - & $\alpha$-Helix C \\
\hline E2110 & Partial & No & - & + & $\alpha$-Helix C \\
\hline V180l & No & No & - & - & $\alpha$-Helix B \\
\hline E196K & No & No & - & + & Between $\alpha$-helix B/C \\
\hline V210l & No & No & - & - & $\alpha$-Helix C \\
\hline M232R & No & No & + & + & GPI anchor signal \\
\hline P238S & No & No & + & - & GPI anchor signal \\
\hline
\end{tabular}

Change in the polarity or the charge of the amino acid by PrP mutation are indicated, using + if there is a change and - if there is no change. The location of the substituted amino acid in the secondary structure of PrP is provided. TM, Transmembrane domain.

\section{References}

Apetri AC, Surewicz K, Surewicz WK (2004) The effect of disease-associated mutations on the folding pathway of human prion protein. J Biol Chem 279:18008-18014.

Baker HE, Poulter M, Crow TJ, Frith CD, Lofthouse R, Ridley RM (1991) Aminoacid polymorphism in human prion protein and age at death in inherited prion disease. Lancet 337:1286.

Bounhar Y, Zhang Y, Goodyer CG, LeBlanc A (2001) Prion protein protects human neurons against Bax-mediated apoptosis. J Biol Chem 276:39145-39149.

Bounhar Y, Mann KK, Roucou X, LeBlanc AC (2006) Prion protein prevents Bax-mediated cell death in the absence of other Bcl-2 family members in Saccharomyces cerevisiae. FEMS Yeast Res 6:1204-1212.

Caughey B, Race RE, Ernst D, Buchmeier MJ, Chesebro B (1989) Prion protein biosynthesis in scrapie-infected and uninfected neuroblastoma cells. J Virol 63:175-181.

Diarra-Mehrpour M, Arrabal S, Jalil A, Pinson X, Gaudin C, Pietu G, Pitaval A, Ripoche H, Eloit M, Dormont D, Chouaib S (2004) Prion protein prevents human breast carcinoma cell line from tumor necrosis factor alpha-induced cell death. Cancer Res 64:719-727.

Dorandeu A, Wingertsmann L, Chretien F, Delisle MB, Vital C, Parchi P, Montagna P, Lugaresi E, Ironside JW, Budka H, Gambetti P, Gray F (1998) Neuronal apoptosis in fatal familial insomnia. Brain Pathol 8:531-537.

Endo T, Groth D, Prusiner SB, Kobata A (1989) Diversity of oligosaccharide structures linked to asparagines of the scrapie prion protein. Biochemistry $28: 8380-8388$

Englund PT (1993) The structure and biosynthesis of glycosyl phosphatidylinositol protein anchors. Annu Rev Biochem 62:121-138.

Ferrer I (2002) Synaptic pathology and cell death in the cerebellum in Creutzfeldt-Jakob disease. Cerebellum 1:213-222.

Gambetti P, Kong Q, Zou W, Parchi P, Chen SG (2003) Sporadic and familial CJD: classification and characterisation. Br Med Bull 66:213-239.

Goldfarb LG, Petersen RB, Tabaton M, Brown P, LeBlanc AC, Montagna P, Cortelli P, Julien J, Vital C, Pendelbury WW, Haltia M, Wills PR, Hauw JJ, McKeever PE, Morani L, Schrank B, Swergold GD, Autilio-Gambetti L, Gajdusek DC, Lugaresi E, Gambetti P (1992) Fatal familial insomnia and familial Creutzfeldt-Jakob disease: disease phenotype determined by a DNA polymorphism. Science 258:806-808.

Gray F, Chretien F, Adle-Biassette H, Dorandeu A, Ereau T, Delisle MB, Kopp N, Ironside JW, Vital C (1999) Neuronal apoptosis in Creutzfeldt-Jakob disease. J Neuropathol Exp Neurol 58:321-328.

Groger R, Morrow D, Tyckocinski M (1989) Directional antisense and sense cloning using Epstein-Barr virus episomal expression vectors. Gene 81:285-294.

Hainfellner JA, Parchi P, Kitamoto T, Jarius C, Gambetti P, Budka H (1999) A novel phenotype in familial Creutzfeldt-Jakob disease: prion protein gene E200K mutation coupled with valine at codon 129 and type 2 protease-resistant prion protein. Ann Neurol 45:812-816.

Hoque MZ, Kitamoto T, Furukawa H, Muramoto T, Tateishi J (1996) Mutation in the prion protein gene at codon 232 in Japanese patients with Creutzfeldt-Jakob disease: a clinicopathological, immunohistochemical and transmission study. Acta Neuropathol 92:441-446.

Kascsak RJ, Rubenstein R, Merz PA, Tonna-DeMasi M, Fersko R, Carp RI, Wisniewski HM, Diringer H (1987) Mouse polyclonal and monoclonal antibody to scrapie-associated fibril proteins. J Virol 61:3688-3693.

Kawashima T, Doh-ura K, Ogomori K, Iwaki T (2001) Apoptotic bodies in the cerebellum of Japanese patients with Creutzfeldt-Jakob disease. Pathol Int 51:140-144.

Keller JN, Gee J, Ding Q (2002) The proteasome in brain aging. Ageing Res Rev 1:279-293.

Kiachopoulos S, Bracher A, Winklhofer KF, Tatzelt J (2005) Pathogenic mutations located in the hydrophobic core of the prion protein interfere with folding and attachment of the glycosylphosphatidylinositol anchor. J Biol Chem 280:9320-9329.

Kovacs GG, Puopolo M, Ladogana A, Pocchiari M, Budka H, van Duijn C, Collins SJ, Boyd A, Giulivi A, Coulthart M, Delasnerie-Laupretre N, Brandel JP, Zerr I, Kretzschmar HA, de Pedro-Cuesta J, Calero-Lara M, Glatzel M, Aguzzi A, Bishop M, Knight R, Belay G, Will R, Mitrova E (2005) Genetic prion disease: the EUROCJD experience. Hum Genet 118:166-174

Kretzschmar HA, Prusiner SB, Stowring LE, DeArmond SJ (1986) Scrapie prion proteins are synthesized in neurons. Am J Pathol 122:1-5.

Kuwahara C, Takeuchi AM, Nishimura T, Haraguchi K, Kubosaki A, Matsumoto Y, Saeki K, Yokoyama T, Itohara S, Onodera T (1999) Prions prevent neuronal cell-line death. Nature 400:225-226.

LeBlanc AC, Papadopoulos M, Belair C, Chu W, Crosato M, Powell J, Goodyer CG (1997) Processing of amyloid precursor protein in human primary neuron and astrocyte cultures. J Neurochem 68:1183-1190.

Lehmann S, Harris DA (1996) Mutant and infectious prion proteins display common biochemical properties in cultured cells. J Biol Chem 271:1633-1637.

Liemann S, Glockshuber R (1999) Influence of amino acid substitutions related to inherited human prion diseases on the thermodynamic stability of the cellular prion protein. Biochemistry 38:3258-3267.

Ma J, Lindquist S (2001) Wild-type PrP and a mutant associated with prion disease are subject to retrograde transport and proteasome degradation. Proc Natl Acad Sci USA 98:14955-14960.

Ma J, Lindquist S (2002) Conversion of PrP to a self-perpetuating PrPSclike conformation in the cytosol. Science 298:1785-1788.

Merry DE, Veis DJ, Hickey WF, Korsmeyer SJ (1994) bcl-2 protein expression is widespread in the developing nervous system and retained in the adult PNS. Development 120:301-311.

Mishra RS, Bose S, Gu Y, Li R, Singh N (2003) Aggresome formation by 
mutant prion proteins: the unfolding role of proteasomes in familial prion disorders. J Alzheimers Dis 5:15-23.

Monari L, Chen SG, Brown P, Parchi P, Petersen RB, Mikol J, Gray F, Cortelli P, Montagna P, Ghetti B, Goldfarb LG, Gajdusek DC, Lugaresi E, Gambetti P, Autilio-Gambetti L (1994) Fatal familial insomnia and familial Creutzfeldt-Jakob disease: different prion proteins determined by a DNA polymorphism. Proc Natl Acad Sci USA 91:2839-2842.

Peoc'h K, Manivet P, Beaudry P, Attane F, Besson G, Hannequin D, Delasnerie-Laupretre N, Laplanche JL (2000) Identification of three novel mutations (E196K, V203I, E211Q) in the prion protein gene (PRNP) in inherited prion diseases with Creutzfeldt-Jakob disease phenotype. Hum Mutat 15:482.

Phaneuf S, Leeuwenburgh C (2002) Cytochrome c release from mitochondria in the aging heart: a possible mechanism for apoptosis with age. Am J Physiol Regul Integr Comp Physiol 282:R423-R430.

Rane NS, Yonkovich JL, Hegde RS (2004) Protection from cytosolic prion protein toxicity by modulation of protein translocation. EMBO J 23:4550-4559.

Riek R, Wider G, Billeter M, Hornemann S, Glockshuber R, Wuthrich K (1998) Prion protein NMR structure and familial human spongiform encephalopathies. Proc Natl Acad Sci USA 95:11667-11672.

Roucou X, LeBlanc AC (2005) Cellular prion protein neuroprotective function: implications in prion diseases. J Mol Med 83:3-11.

Roucou X, Guo Q, Zhang Y, Goodyer CG, LeBlanc AC (2003) Cytosolic prion protein is not toxic and protects against Bax-mediated cell death in human primary neurons. J Biol Chem 278:40877-40881.

Roucou X, Gains M, LeBlanc AC (2004) Neuroprotective functions of prion protein. J Neurosci Res 75:153-161.

Roucou X, Giannopoulos PN, Zhang Y, Jodoin J, Goodyer CG, LeBlanc A (2005) Cellular prion protein inhibits proapoptotic Bax conformational change in human neurons and in breast carcinoma MCF-7 cells. Cell Death Differ 12:783-795.

Savory J, Rao JK, Huang Y, Letada PR, Herman MM (1999) Age-related hippocampal changes in Bcl-2:Bax ratio, oxidative stress, redox-active iron and apoptosis associated with aluminum-induced neurodegeneration: increased susceptibility with aging. Neurotoxicology 20:805-817.

Tahiri-Alaoui A, Gill AC, Disterer P, James W (2004) Methionine 129 vari- ant of human prion protein oligomerizes more rapidly than the valine 129 variant: implications for disease susceptibility to Creutzfeldt-Jakob disease. J Biol Chem 279:31390-31397.

Vetrugno V, Malchow M, Liu Q, Marziali G, Battistini A, Pocchiari M (1999) Expression of wild-type and V210I mutant prion protein in human neuroblastoma cells. Neurosci Lett 270:41-44.

Wadsworth JD, Asante EA, Desbruslais M, Linehan JM, Joiner S, Gowland I, Welch J, Stone L, Lloyd SE, Hill AF, Brandner S, Collinge J (2004) Human prion protein with valine 129 prevents expression of variant CJD phenotype. Science 306:1793-1796.

Walmsley AR, Hooper NM (2003) Distance of sequons to the C-terminus influences the cellular N-glycosylation of the prion protein. Biochem J 370:351-355.

Wang X, Wang F, Arterburn L, Wollmann R, Ma J (2006) The interaction between cytoplasmic prion protein and the hydrophobic lipid core of membrane correlates with neurotoxicity. J Biol Chem 281:13559-13565.

White FA, Keller-Peck CR, Knudson CM, Korsmeyer SJ, Snider WD (1998) Widespread elimination of naturally occurring neuronal death in Baxdeficient mice. J Neurosci 18:1428-1439.

Windl O, Giese A, Schulz-Schaeffer W, Zerr I, Skworc K, Arendt S, Oberdieck C, Bodemer M, Poser S, Kretzschmar HA (1999) Molecular genetics of human prion diseases in Germany. Hum Genet 105:244-252.

Winklhofer KF, Heske J, Heller U, Reintjes A, Muranyi W, Moarefi I, Tatzelt J (2003) Determinants of the in vivo folding of the prion protein. A bipartite function of helix 1 in folding and aggregation. J Biol Chem 278:14961-14970.

Wopfner F, Weidenhofer G, Schneider R, von Brunn A, Gilch S, Schwarz TF, Werner T, Schatzl HM (1999) Analysis of 27 mammalian and 9 avian PrPs reveals high conservation of flexible regions of the prion protein. J Mol Biol 289:1163-1178.

Yedidia Y, Horonchik L, Tzaban S, Yanai A, Taraboulos A (2001) Proteasomes and ubiquitin are involved in the turnover of the wild-type prion protein. EMBO J 20:5383-5391.

Zanusso G, Petersen RB, Taocong J, Jing Y, Kanoush R, Ferrari S, Gambetti P, Singh N (1999) Proteosomal degradation and N-terminal protease resistance of the codon 145 mutant prion protein. J Biol Chem 274:2339623404. 